\title{
DNA Integration
}

National Cancer Institute

\section{Source}

National Cancer Institute. DNA Integration. NCI Thesaurus. Code C18855.

Any DNA sequence rearrangement in which double-stranded DNA from a donor

molecule is incorporated into host DNA by the action of an integrase, yielding a single, stable, replication-competent, double-stranded DNA product. 